\title{
Sistem Pendukung Keputusan Penentuan Pemenang Tender Pekerjaan Konstruksi dengan Metode Fuzzy AHP
}

\author{
Peggi Sri Astuti*1, Retantyo Wardoyo ${ }^{2}$ \\ ${ }^{1}$ Ruang Baca Dekanat Fakultas Teknik, Universitas Udayana, Bali \\ ${ }^{2}$ Jurusan Ilmu Komputer dan Elektronika, FMIPA UGM, Yogyakarta \\ e-mail: ${ }^{* 1}$ peggisriastuti@yahoo.co.id, ${ }^{2}$ rw@ugm.ac.id
}

\begin{abstract}
Abstrak
Pengambilan keputusan dalam penentuan pemenang tender pekerjaan konstruksi (tidak kompleks) pada pembangunan gedung kuliah Fakultas Ekonomi Univesitas Udayana (UNUD) oleh panitia tender di Bagian Perlengkapan Rektorat UNUD masih dilakukan secara manual (dengan software Microsoft Excel dan Word), sehingga untuk membantu dan mempercepat pengambilan keputusan tersebut (dalam situasi beberapa/banyak peserta tender memenuhi semua evaluasi kriteria dan memiliki harga penawaran terkoreksi terendah yang sama di bawah HPS) maka penelitian ini bertujuan untuk membangun SPK (Sistem Pendukung Keputusan) dengan metode Fuzzy AHP. Versi Fuzzy AHP yang dipakai adalah model Chang (1992) karena memiliki langkah-langkah sederhana dan mudah diaplikasikan pada penelitian ini. Hasil penelitian menunjukkan bahwa SPK yang dibangun menghasilkan perangkingan peserta 1, 2, dan 3 yang sama dengan sistem manual yang ada di Bagian Perlengkapan Rektorat UNUD, meskipun perangkingan 4, 5, 6 yang juga dihasilkan SPK ini tidak ada di sistem manual karena perangkingan 4, 5, 6 tidak memenuhi evaluasi kriteria kualifikasi (syarat untuk lulus tender adalah memenuhi semua evaluasi kriteria). Maka disimpulkan bahwa SPK yang dibangun menghasillkan informasi yang valid.
\end{abstract}

Kata kunci-sistem pendukung keputusan, fuzzy AHP, tender, pekerjaan konstruksi

\begin{abstract}
Decision-making to determine the winner of project tender (not complex one) on the construction of college buildings for Economics Faculty of Udayana University by tender committee at the Rectorate Equipment Section of Udayana University, still is carried out manually (applying Microsoft Excel and Word), so to assist and accelerate the decision (in this situation a few/many bidders met all evaluation criteria and have the same lowest bidding price corrected under HPS), this study aims to build a DSS (Decision Supporting System) with Fuzzy AHP method. The applied Fuzzy AHP version is Chang model (1992) because it has simple steps and easy to apply in this study. The results showed that SPK produced ranking method of 1, 2, and 3 that are similar to the existing manual system in Equipment Section of the Rectorate, though the ranking method of 4, 5, 6, which also produced by SPK, is not contained in the manual system because ranking method of 4, 5, 6 did not meet the qualifying criteria evaluation (a requirement for graduation is to fulfill all tender evaluation criteria). It, therefore, comes to conclude that the DSS produce valid information.
\end{abstract}

Keywords — decision supporting system, fuzzy AHP, tender, construction project 


\section{PENDAHULUAN}

$\mathrm{D}_{\mathrm{p}}^{\mathrm{a}}$ alam rangka penyediaan sarana dan fasilitas proses belajar mengajar di lembaga pendidikan, maka Universitas Udayana Bali sebagai salah satu institusi pemerintah di bidang pendidikan menambah sebuah gedung kuliah Fakultas Ekonomi di lokasi Denpasar dan menyusun pelaksanaan pekerjaan konstruksi melalui pelelangan umum. Pelelangan umum itu dilakukan dengan metode penilaian pascakualifikasi dengan metode evaluasi sistem gugur karena pekerjaan itu merupakan pekerjaan tidak kompleks dan umumnya dana yang diperlukan di atas 200 juta dan tidak lebih dari 100 milyar rupiah.

Pengambilan keputusan dalam penentuan pemenang tender untuk pekerjaan konstruksi (tidak kompleks) yang dilakukan panitia tender di Bagian Perlengkapan Rektorat Universitas Udayana masih dilakukan secara manual (masih berupa software Microsoft Excel dan Word), sehingga untuk membantu dan mempercepat pengambilan keputusan tersebut (dalam situasi beberapa/banyak peserta tender memenuhi semua evaluasi kriteria dan memiliki harga penawaran terkoreksi terendah di bawah HPS yang sama) maka penelitian ini bertujuan untuk membangun SPK (Sistem Pendukung Keputusan) dengan metode Fuzzy AHP. Versi Fuzzy AHP yang dipakai adalah model Chang (1992) karena memiliki langkah-langkah sederhana dan mudah diaplikasikan pada penelitian ini $[1,2]$. Fungsi keanggotaan fuzzy yang dipakai adalah TFN (Triangular Fuzzy Number) $[3,4]$.

\section{METODE PENELITIAN}

\subsection{Langkah-Langkah Model Chang}

Menurut [1], langkah-langkah fuzzy AHP pada model Chang adalah:

1. Menghitung fuzzy synthetic extents $\left(\tilde{S}_{x}\right)$ dari matrik pairwise comparison (TFN) antar kriteria/subkriteria pada kriteria/subkriteria ke $x$ dengan persamaan:

$\tilde{S}_{x}=\sum_{y=1}^{n} \tilde{C}_{x y} \otimes\left[\sum_{k=1}^{n} \sum_{y=1}^{n} \tilde{C}_{k y}\right]^{-1} ; x=1,2, \ldots, n$

dimana $n$ adalah ukuran matrik pairwise comparison antar kriteria/subkriteria, $k$ adalah

gabungan kriteria dari baris ke $i$ dimana $\mathrm{i}=1$ sampai $n$.

$\sum_{y=1}^{n} \tilde{C}_{x y}=\left(\sum_{y=1}^{n} l_{x y}, \sum_{y=1}^{n} m_{x y}, \sum_{y=1}^{n} u_{x y}\right) ; x=1,2, \ldots, n$

dimana $l$ adalah batas bawah, $m$ adalah batas tengah, $u$ adalah batas atas.

$\left[\sum_{k=1}^{n} \sum_{y=1}^{n} \tilde{C}_{k y}\right]^{-1}=\left[\frac{1}{\sum_{k=1}^{n} \sum_{y=1}^{n} u_{k y}}, \frac{1}{\sum_{k=1}^{n} \sum_{y=1}^{n} m_{k y}}, \frac{1}{\sum_{k=1}^{n} \sum_{y=1}^{n} l_{k y}}\right]$

$\sum_{k=1}^{n} \sum_{y=1}^{n} \tilde{C}_{k y}=\left(\sum_{k=1}^{n} \sum_{y=1}^{n} l_{k y}, \sum_{k=1}^{n} \sum_{y=1}^{n} m_{k y}, \sum_{k=1}^{n} \sum_{y=1}^{n} u_{k y}\right)=$

$\left[\left(\sum_{y=1}^{n} l_{1 y}, \sum_{y=1}^{n} m_{1 y}, \sum_{y=1}^{n} u_{1 y}\right)+\ldots+\left(\sum_{y=1}^{n} l_{n y}, \sum_{y=1}^{n} m_{n y}, \sum_{y=1}^{n} u_{n y}\right)\right]$

2. Membandingkan nilai fuzzy synthetic extents $\left(\tilde{S}_{x}\right)$ kriteria/subkriteria yang satu dengan fuzzy synthetic extents $\left(\tilde{S}_{y}\right)$ kriteria/subkriteria yang lain, yang disebut degree of possibilitydengan persamaan:

$$
\begin{aligned}
& V\left(\tilde{S}_{x} \geq \tilde{S}_{y}\right)=\left\{\begin{array}{l}
0, \text { jika } m_{x}>=m_{y} \\
1, \text { jika } l_{y}>=u_{x} \\
\frac{l_{y}-u_{x}}{\left(m_{x}-u_{x}\right)-\left(m_{y}-l_{y}\right)}, \text { jika tidak memenuhi } m_{x}>=m_{y} \text { dan }
\end{array}\right. \\
& l_{y}>=u_{x}
\end{aligned}
$$

dimana $V\left(\tilde{S}_{x} \geq \tilde{S}_{y} \mid \mathrm{y}=1, \ldots, \mathrm{n} ; \mathrm{y} \neq \mathrm{x}\right)$ dan banyak kemungkinan (n-1).

3. Menentukan minimum degree of possibility dari $V\left(\tilde{S}_{x} \geq \tilde{S}_{y}\right)$

4. Tentukan vector bobot kepentingan yang dinormalisasikan $W=\left(w_{1}, w_{2}, \ldots, w_{n}\right)$ dari matrik pairwise comparison dengan persamaan:

$w_{x}=\frac{V\left(\tilde{S}_{x} \geq \tilde{S}_{y} \mid y=1, \ldots, n ; y \neq x\right)}{\sum_{k=1}^{n} V\left(\tilde{S}_{k} \geq \tilde{S}_{y} \mid y=1, \ldots, n ; y \neq k\right)} ; x=1, \ldots, n$

dimana $w_{x}$ adalah angka-angka nonfuzzy.

IJCCS Vol. 8, No. 1, January 2014 : 1 - 12 


\subsection{Fungsi Keanggotaan Skala TFN Dalam Variabel Linguistik}

Fungsi keanggotaan skala TFN dalam variabel linguistik dipakai untuk membandingkan dua kriteria, dua subkriteria, dan dua peserta yang terdapat pada Tabel 1.

Tabel 1 Fungsi keanggotaan skala TFN dalam variabel linguistik

\begin{tabular}{|c|c|c|c|c|}
\hline Skala AHP & $\begin{array}{l}\text { Variabel linguistik untuk } \\
\text { kriteria/subkriteria }\end{array}$ & $\begin{array}{l}\text { Variabel linguistik } \\
\text { untuk alternatif }\end{array}$ & $\begin{array}{c}\text { Selisih nilai } \\
\text { untuk } \\
\text { alternatif }\end{array}$ & Skala fuzzy/TFN \\
\hline 1 & Sama penting (SP) & Sama baik (SB) & 0 & $\begin{array}{c}\tilde{1}=(1,1,3), \\
\text { kecuali diagonal } \\
(1,1,1)\end{array}$ \\
\hline 2 & Hampir cukup penting (HCP) & $\begin{array}{l}\text { Hampir cukup baik } \\
\text { (HCB) }\end{array}$ & $0,5-1$ & $\tilde{2}=(1,2,4)$ \\
\hline 3 & Cukup penting (CP) & Cukup baik (CB) & $1,5-2$ & $\widetilde{3}=(1,3,5)$ \\
\hline 4 & Hampir lebih penting (HLP) & $\begin{array}{l}\text { Hampir lebih baik } \\
\text { (HLB) }\end{array}$ & $>2$ & $\tilde{4}=(2,4,6)$ \\
\hline 5 & Lebih penting (LP) & & & $\tilde{5}=(3,5,7)$ \\
\hline $1 / 2$ & $\begin{array}{l}\text { Hampir cukup tidak penting } \\
\text { (HCTP) }\end{array}$ & $\begin{array}{l}\text { Hampir cukup tidak } \\
\text { baik (HCTB) }\end{array}$ & $0,5-1$ & $\widetilde{1 / 2}=(1 / 4,1 / 2,1)$ \\
\hline $1 / 3$ & Cukup tidak penting (CTP) & $\begin{array}{c}\text { Cukup tidak baik } \\
\text { (CTB) }\end{array}$ & $1,5-2$ & $\widetilde{1 / 3}=(1 / 5,1 / 3,1)$ \\
\hline $1 / 4$ & $\begin{array}{l}\text { Hampir lebih tidak penting } \\
\text { (HLTP) }\end{array}$ & $\begin{array}{l}\text { Hampir lebih tidak baik } \\
\text { (HLTB) }\end{array}$ & $>2$ & $\widetilde{1 / 4}=(1 / 6,1 / 4,1 / 2)$ \\
\hline $1 / 5$ & Lebih tidak penting (LTP) & & & $\widetilde{1 / 5}=(1 / 7,1 / 5,1 / 3)$ \\
\hline
\end{tabular}

\subsection{Tahap-Tahapan Metode Fuzzy AHP}

Tahap-tahapan metode fuzzy AHP adalah:

2.3.1 Definisikan Masalah dan Identifikasikan Tujuan, Kriteria, Subkriteria, dan Alternatif Alternatif Keputusan

Tujuan penelitian ini adalah membangun SPK penentuan pemenang tender pekerjaan konstruksi (tidak kompleks) dengan ditenttukan 4 kriteria: administrasi (AD), teknis (TK), harga $(\mathrm{HG})$, dan Kualifikasi (KL). Administrasi memiliki 4 subkriteria: surat penawaran $\left(\mathrm{AD}_{1}\right)$, surat jaminan penawaran $\left(\mathrm{AD}_{2}\right)$, daftar kuantitas dan harga/RAB $\left(\mathrm{AD}_{3}\right)$, analisa harga satuan mata pembayaran utama $\left(\mathrm{AD}_{4}\right)$. Teknis memiliki 5 subkriteria: metode pelaksanaan dan gambar $\left(\mathrm{TK}_{1}\right)$, jadwal pelaksanaan $\left(\mathrm{TK}_{2}\right)$, spesifikasi teknis $\left(\mathrm{TK}_{3}\right)$, daftar peralatan utama $\left(\mathrm{TK}_{4}\right)$, daftar personil inti $\left(\mathrm{TK}_{5}\right)$. Harga memiliki 3 subkriteria: harga penawaran terkoreksi di bawah pagu anggaran $\left(\mathrm{HG}_{1}\right)$, harga penawaran terkoreksi di bawah $\mathrm{HPS}\left(\mathrm{HG}_{2}\right)$, preferensi harga atas tingkat komponen dalam negeri $\left(\mathrm{HG}_{3}\right)$. Kualifikasi memiliki 8 subkriteria: surat pernyataan $\left(\mathrm{KL}_{1}\right)$; ijin usaha jasa konstruksi, sertifikat badan usaha, tanda daftar perusahaan $\left(\mathrm{KL}_{2}\right)$, kondisi keuangan $\left(\mathrm{KL}_{3}\right)$; surat kemitraan, pakta integritas $\left(\mathrm{KL}_{4}\right)$; struktur organisasi $\left(\mathrm{KL}_{5}\right)$; pengalaman perusahaan 4 th terakhir, daftar perolehan pekerjaan yang sedang dikerjakan, daftar personil inti $\left(\mathrm{KL}_{6}\right)$; dokumen pajak $\left(\mathrm{KL}_{7}\right)$; formulir isian penilaian kualifikasi $\left(\mathrm{KL}_{8}\right)$. Alternatif-alternatif keputusan terdiri 6 peserta tender: CV.Sri Karya (SK), CV.Ari Wiguna Jaya (AWJ), PT.Ubung Raya (UR), CV.Asta Bumi (AB), CV.Marga Jaya (MJ), CV.Artha Dananjaya (AD).

2.3.2 Membuat Struktur Hirarki AHP

Struktur hirarki AHP terdiri dari tujuan (level 1), kriteria (level 2), subkriteria (level 3), dan alternatif (level 4).

\subsubsection{Memberikan Nilai Matrik Pairwise Comparison (TFN) Antar Kriteria}

Memberikan nilai matrik antar kriteria (perbandingan antar baris $(x)$ dengan kolom $(y)$ ) sesuai Tabel 1 yang berada di atas diagonal yang berniai satu. Nilai yang berada di bawah diagonal yang bernilai satu bersifat kebalikan/resiprokal di mana $l$ (batas bawah) menjadi $1 / u, m$ (batas tengah) menjadi $1 / m, u$ (batas atas) menjadi 1.l.

2.3.4 Menghitung Fuzzy Synthetic Extents Kriteria

Diawali dengan persamaan (2), lalu dilanjutkan persamaan (4), (3), (1).

\subsubsection{Menghitung Degree of Possibility Kriteria}

Diawali dengan persamaan (5), lalu mencari minmum degree of possibility dari hasil persamaan (1) dan dilanjutkan persamaan (6). 
2.3.6 Mengecek Rasio Konsistensi Semua Kriteria dan Revising Judgement (Kalau Ada)

Diawali dengan membuat matrik $\lambda$ (ukuran sesuai jumlah kriteria/subkriteria) dengan rumus geomean di mana nilai matrik kriteria satu (baris atau $x$ ) terhadap kriteria lain (kolom atau $y$ ) adalah geomean $\left(l_{x y}, m_{x y}, u_{x y}\right)$ dari matrik pairwise comparison (TFN) antar kriteria dikali dengan hasil pembagian antara normalisasi kriteria $y$ dengan normalisasi kriteria $x$. Geomean $\left(l_{x}, m_{x}, u_{x}\right)$ adalah $\sqrt[n]{\left(l_{x y} * m_{x y} * u_{x y}\right)}$ di mana $n$ merupakan banyaknya bilangan. Kemudian hitung jumlah $\lambda$ pada tiap-tiap kolom pada matrik $\lambda$. Dilanjutkan hitung $\lambda$ maksimum dengan hitung geomean dari seluruh nilai jumlah $\lambda$ pada tiap-tiap kolom. Lalu hitung CI (Indeks Konsistensi),yaitu: $(\lambda$ maksimum $-n) /(n-1)$ di mana $n$ merupakan banyak kriteria/subkriteria. Setelah itu hitung CR (rasio konsistensi), yaitu: CI/RI di mana RI (Indeks random) sesuai ukuran matrik pada skala Saaty (AHP). Jika CR telah memenuhi $<=0,1$ dan tidak negatip, maka dilanjutkan ke tahap berikutnya.

Jika CR belum memenuhi, maka dapat menghitung revising judgement. Diawali dengan membuat matrik rasio prioritas (ukuran sesuai jumlah kriteria/subkriteria). Hitung nilai matrik kriteria satu (baris atau $x$ ) terhadap kriteria lain (kolom atau $y$ ) dengan mengabsolutkan dari hasil pengurangan antara geomean $\left(\left(l_{x}, m_{x}, u_{x}\right)\right.$ dari matrik pairwise comparison (TFN) antar kriteria dengan hasil pembagian antara normalisasi kriteria $x$ dengan normalisasi kriteria $y$. Setelah itu hitung total nilai matrik rasio pada tiap-tiap baris. Tentukan total maksimum tersebut, maka didapatkan nomer baris yang memiliki nilai maksimum. Setelah itu tentukan nilai maksimum dari deretan baris yang memiliki total maksimum, sehingga didapatkan nomer kolom. Maka didapatkan nomer baris dan nomer kolom yang dapat diubah nilainya pada tahap memberikan nilai matrik pairwise comparison (TFN) antar kriteria (tahap 3.1.3). Kemudian dilanjutkan ke tahap $(3.1 .4,3.1 .5,3.1 .6)$ hingga didapatkan $\mathrm{CR}$ memenuhi $<=0,1$ dan tidak negatip.

2.3.7 Memberikan Nilai Matrik Pairwise Comparison (TFN) Antar Subkriteria Pada Semua Kriteria

Tahap ini dilakukan untuk semua kriteria dan caranya sama dengan tahap (3.1.3).

2.3.8 Menghitung Fuzzy Synthetic Extents Semua Subkriteria Pada Semua Kriteria

Tahap ini sama caranya dengan tahap (3.1.4).

2.3.9 Menghitung Degree of Possibility Semua Subkriteria Pada Semua Kriteria

Tahap ini sama dengan caranya dengan tahap (3.1.5).

2.3.10 Mengecek Rasio Konsistensi Subkriteria Pada Semua Kriteria dan Revising Judgement (Kalau Ada)

Tahap ini sama caranya dengan tahap (3.1.6). Semua subkriteria yang dimiliki pada tiap-tiap kriteria harus memenuhi CR $<=0,1$ dan tidak negatip.

2.3.11 Menghitung Composite Weight Semua Subkriteria

Dilakukan dengan mengalikan normalisasi kriteria dengan normalisasi subkriteria yang dimiliki kriteria tersebut.

\subsubsection{Memberikan Nilai Peserta Tender}

Memberikan nilai peserta dari rentang nilai 0 sampai 10 dengan kelipatan 0,5 untuk semua subkriteria. Nilai 10 atau 6-10 untuk subkriteria $\mathrm{HG}_{2}, \mathrm{GH}_{3}$ artinya ada dan sesuai, nilai 5 artinya ada dan tidak sesuai, nilai 0 artinya tidak ada. Jika dalam kondisi beberapa/banyak peserta mememuhi semua evaluasi kriteria dan memiliki harga penawaran terkoreksi terendah yang sama di bawah HPS, maka untuk subkriteria $\mathrm{TK}_{1}-\mathrm{TK}_{5}$ nilai 6-10 artinya ada dan sesuai. Data nilai peserta ada pada Tabel 2.

2.3.13 Menghitung Nilai Matrik Pairwise Comparison (TFN) Antar Peserta Pada Tiap-Tiap Subkriteria

Dilakukan dengan menghitung selisih antar nilai peserta satu (baris atau $x$ ) dengan peserta lain (kolom atau y) untuk tiap-tiap subkriteria pada matrik yang berada di atas diagonal bernilai satu. Kemudian selisih itu dikelompokkan dalam skala selisih nilai untuk alternatif sesuai Tabel 1.

IJCCS Vol. 8, No. 1, January 2014: $1-12$ 


\subsubsection{Menghitung Fuzzy Synthetic Extents Peserta Untuk Tiap-Tiap Subkriteria}

Tahap ini sama caranya dengan tahap (3.1.4 dan 3.1.8).

2.3.15 Menghitung Degree of Possibility Peserta Untuk Tiap-Tiap Subkriteria

Tahap ini sama caranya dengan tahap (3.1.5 dan 3.1.9).

\subsubsection{Menghitung Bobot Akhir Peserta Untuk Semua Subkriteria}

Dilakukan dengan mengalikan nilai composite weight subkriteria dengan normalisasi peserta pada subkriteria tersebut.

\subsubsection{Menghitung Total Bobot Akhir dan Rangking Peserta}

Dari hasil total bobot akhir dari semua subkriteria untuk tiap-tiap peserta, didapatkan perangkingan peserta yang dimulai dengan perangkingan teratas dari nilai total bobot akhir terbesar. Total bobot akhir dan rangking peserta terdapat pada Tabel 3.

Tabel 2 Nilai peserta tender

\begin{tabular}{|c|c|c|c|c|c|c|}
\hline \multirow{2}{*}{ Subkriteria } & $\begin{array}{c}\text { CV. Sri } \\
\text { Karya } \\
\text { (SK) }\end{array}$ & $\begin{array}{c}\text { CV. Ari } \\
\text { Wiguna Jaya } \\
\text { (AWJ) }\end{array}$ & $\begin{array}{c}\text { PT.Ubung } \\
\text { Raya (UR) }\end{array}$ & $\begin{array}{c}\text { CV. Asta } \\
\text { Bumi (AB) }\end{array}$ & $\begin{array}{c}\text { CV. Marga } \\
\text { Jaya (MJ) }\end{array}$ & $\begin{array}{c}\text { CV. Artha } \\
\text { Dananjaya } \\
\text { (AD) }\end{array}$ \\
\cline { 2 - 7 } & Nilai & Nilai & Nilai & Nilai & Nilai & Nilai \\
\hline $\mathbf{A D}_{\mathbf{1}}$ & 10 & 10 & 10 & 10 & 10 & 10 \\
\hline $\mathbf{A D}_{\mathbf{2}}$ & 10 & 10 & 10 & 10 & 10 & 10 \\
\hline $\mathbf{A D}_{\mathbf{3}}$ & 10 & 10 & 10 & 10 & 10 & 10 \\
\hline $\mathbf{A D}_{\mathbf{4}}$ & 10 & 10 & 10 & 10 & 10 & 10 \\
\hline $\mathbf{T K}_{\mathbf{1}}$ & 8 & 7,5 & 10 & 9 & 7 & 7 \\
\hline $\mathbf{T K}_{\mathbf{2}}$ & 8 & 7 & 9 & 8,5 & 8 & 7 \\
\hline $\mathbf{T K}_{\mathbf{3}}$ & 9 & 6,5 & 9 & 9 & 6,5 & 7 \\
\hline $\mathbf{T K}_{\mathbf{4}}$ & 9 & 8 & 10 & 10 & 8 & 8 \\
\hline $\mathbf{T K}_{\mathbf{5}}$ & 10 & 10 & 10 & 10 & 10 & 10 \\
\hline $\mathbf{H G}_{\mathbf{1}}$ & 10 & 10 & 10 & 10 & 10 & 10 \\
\hline $\mathbf{H G}_{\mathbf{2}}$ & 9 & 6,5 & 9 & 9 & 6,5 & 7 \\
\hline $\mathbf{H G}_{\mathbf{3}}$ & 9 & 6,5 & 9 & 9 & 6,5 & 7 \\
\hline $\mathbf{K L}_{\mathbf{1}}$ & 10 & 10 & 10 & 10 & 10 & 5 \\
\hline $\mathbf{K L}_{\mathbf{2}}$ & 10 & 5 & 10 & 10 & 5 & 5 \\
\hline $\mathbf{K L}_{\mathbf{3}}$ & 10 & 10 & 10 & 10 & 10 & 5 \\
\hline $\mathbf{K L}_{\mathbf{4}}$ & 10 & 10 & 10 & 10 & 10 & 10 \\
\hline $\mathbf{K L}_{\mathbf{5}}$ & 10 & 10 & 10 & 10 & 10 & 10 \\
\hline $\mathbf{K L}_{\mathbf{6}}$ & 10 & 5 & 10 & 10 & 5 & 5 \\
\hline $\mathbf{K L}_{\mathbf{7}}$ & 10 & 5 & 10 & 10 & 10 & 10 \\
\hline $\mathbf{K L}_{\mathbf{8}}$ & 10 & 10 & 10 & 10 & 10 & 10 \\
\hline
\end{tabular}

Tabel 3 Total bobot akhir dan rangking peserta

\begin{tabular}{|c|c|c|}
\hline Peserta Tender & Total Bobot Akhir & Rangking \\
\hline PT. Ubung Raya (UR) & 0,1939 & 1 \\
\hline CV. Asta Bumi (AB) & 0,1923 & 3 \\
\hline CV. Sri Karya (SK) & 0,1883 & 4 \\
\hline $\begin{array}{c}\text { CV. Artha Dananjaya } \\
\text { (AD) }\end{array}$ & 0,1509 & 5 \\
\hline $\begin{array}{c}\text { CV. Ari Wiguna Jaya } \\
\text { (AWJ) }\end{array}$ & 0,1418 & 6 \\
\hline CV. Marga Jaya (MJ) & 0,1328 & 3 \\
\hline
\end{tabular}

\subsection{Diagram Konteks}

Diagram konteks merupakan gambaran aplikasi secara umum keseluruhan SPK penentuan pemenang tender pekerjaan konstruksi dengan metode fuzzy AHP. Ada 2 eksternal entitas yang digambarkan pada diagram ini, yaitu: admin dan panitia tender. Admin mengimputkan data master (paket pekerjaan konstruksi, detail keterangan perusahaan, perusahaan yang ikut tender, fuzzy linguistik, kriteria, subkriteria, user untuk admin), nilai matrik pairwise comparison (skala AHP) untuk kriteria/subkriteria ke sistem. Panitia tender menginputkan nilai peserta dan user untuk panitia ke sistem. Dari sistem, admin menerima informasi CR untuk kriteria/subkriteria, nomer baris dan kolom untuk diubah nilai matrik pairwise comparison (skala AHP) untuk kriteria/subkriteria. Panitia tender akan menerima 
laporan detail bobot akhir tiap-tiap peserta untuk semua subkriteria dan laporan total bobot akhir dan rangking peserta dari sistem. Diagram konteks terdapat pada Gambar 1.

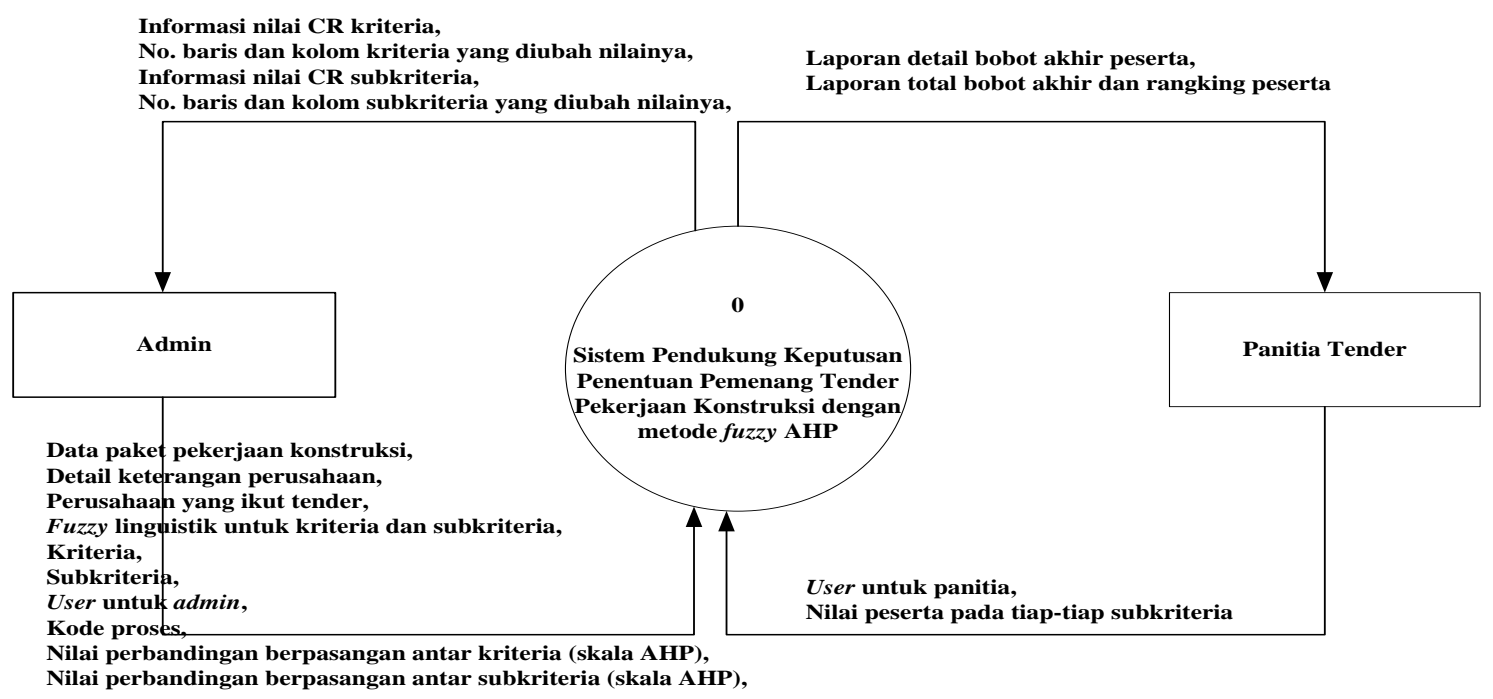

Gambar 1 Diagram konteks

\subsection{Rancangan ERD (Entity Relationship Diagram)}

Aturan bisnis mengenai relasi antar entitas dalam rancangan basis data SPK ini adalah:

1. Satu fuzzy synthetic extents subkriteria menghasilkan satu degree possibility subkriteria.

2. Satu proses memakai semua fuzzy synthetic extents subkriteria.

3. Satu subkriteria memiliki satu fuzzy synthetic extents subkriteria.

4. Satu degree of possibility subkriteria (dpsubkriteria) menghasilkan satu composite weight.

5. Satu subkriteria memiliki satu composite weight.

6. Beberapa subkriteria dimiliki oleh satu kriteria.

7. Satu subkriteria memiliki beberapa nilai peserta.

8. Satu subkriteria memiliki beberapa fuzzy banding subkriteria.

9. Satu subkriteria memiliki beberapa fuzzy synthetic extents peserta.

10. Beberapa composite weight dihasilkan dari satu degree of possibility kriteria.

11. Satu composite weight menghasilkan beberapa bobot akhir.

12. Satu proses memakai semua fuzzy banding subkriteria.

13. Satu proses memakai semua nilai peserta.

14. Satu proses memakai semua fuzzy banding kriteria.

15. Satu proses memakai semua fuzzy synthetic extents kriteria.

16. Satu proses memakai semua fuzzy synthetic extents peserta.

17. Satu fuzzy linguistik memiliki beberapa atau semua fuzzy banding subkriteria.

18. Satu fuzzy linguistik memiliki beberapa atau semua fuzzy banding kriteria.

19. Banyak proses dimiliki oleh satu user.

20. Banyak fuzzy synthetic extents peserta dimiliki oleh satu tender.

21. Satu fuzzy synthetic extents peserta menghasilkan satu degree of possibility peserta.

22. Satu degree of possibility peserta menghasilkan satu bobot akhir.

23. Beberapa nilai peserta dimiliki oleh satu tender.

24. Satu peserta memiliki banyak tender.

25. Satu tender memiliki satu rangking.

26. Satu paket pekerjaan mengikuti banyak tender.

27. Satu fuzzy synthetic extents kriteria dimiliki oleh satu kriteria.

28. Satu fuzzy synthetic extents kriteria menghasilkan satu degree of possibility kriteria.

29. Satu kriteria memiliki beberapa fuzzy banding kriteria.

IJCCS Vol. 8, No. 1, January 2014 : $1-12$ 


\section{HASIL DAN PEMBAHASAN}

\subsection{Pengujian Proses Melakukan Perhitungan Kriteria}

\subsubsection{Proses Memberikan Nilai Matrik Pairwise Comparison (TFN) Antar Kriteria}

Proses ini dilakukan admin dengan menginputkan nilai matrik dengan skala AHP (1-5) di atas diagonal yang bernilai satu dan kode proses $\left(\mathrm{P}_{1}\right)$. Nilai matrik yang berada di bawah diagonal satu akan muncul otomatis karena merupakan kebalikannya. Kode proses ini akan menandai memiliki nilai normalisasi kriteria dan subkriteria tertentu yang akan bisa dipakai untuk melakukan perhitungan untuk peserta tender pada paket pekerjaan konstruksi (tidak kompleks) yang lain.

Input utama yang dipakai untuk proses ini adalah data kriteria dan fuzzy linguistik yang terdapat pada database. Hasil proses ini menghasilkan matrik pairwise comparison (TFN) antar kriteria pada Tabel 4.

Tabel 4 Matrik pairwise comparison (TFN) antar kriteria

\begin{tabular}{|c|c|c|c|c|c|c|c|c|c|c|c|c|}
\hline \multirow{3}{*}{ Kriteria } & \multicolumn{12}{|c|}{ Kriteria } \\
\hline & \multicolumn{3}{|c|}{ AD } & \multicolumn{3}{|c|}{ HG } & \multicolumn{3}{|c|}{ TK } & \multicolumn{3}{|c|}{ KL } \\
\hline & $l_{1}$ & $m_{I}$ & $u_{1}$ & $l_{2}$ & $m_{2}$ & $u_{2}$ & $l_{3}$ & $m_{3}$ & $u_{3}$ & $l_{4}$ & $m_{4}$ & $u_{4}$ \\
\hline AD & 1 & 1 & 1 & 1 & 2 & 4 & 2 & 4 & 6 & 2 & 4 & 6 \\
\hline HG & 0,25 & 0,5 & 1 & 1 & 1 & 1 & 1 & 3 & 5 & 1 & 3 & 5 \\
\hline TK & 0,1667 & 0,25 & 0,5 & 0,2 & 0,3333 & 1 & 1 & 1 & 1 & 1 & 1 & 3 \\
\hline KL & 0,1667 & 0,25 & 0,5 & 0,2 & 0,3333 & 1 & 0,3333 & 1 & 1 & 1 & 1 & 1 \\
\hline
\end{tabular}

\subsubsection{Proses Menghitung Fuzzy Synthetic Extents Kriteria}

Admin harus memilih kode proses yang telah dimasukkan sebelumnya. Input utama pada proses ini adalah nilai matrik pairwise comparison (TFN) antar kriteria yang terdapat pada database. Hasil proses ini terdapat pada Tabel 5.

Tabel 5 Fuzzy synthetic extents kriteria

\begin{tabular}{|c|c|c|c|}
\hline Kode Kriteria & $\mathbf{S}_{\mathbf{1}}$ & $\mathbf{S}_{\mathbf{m}}$ & $\mathbf{S}_{\mathbf{u}}$ \\
\hline $\mathrm{AD}$ & 0.1578 & 0.4653 & 1.2767 \\
\hline $\mathrm{HG}$ & 0.0855 & 0.3172 & 0.9012 \\
\hline $\mathrm{TK}$ & 0.0622 & 0.1093 & 0.413 \\
\hline $\mathrm{KL}$ & 0.0447 & 0.1093 & 0.2629 \\
\hline
\end{tabular}

\subsubsection{Proses Menghitung Degree of Possibility Kriteria}

Admin harus memilih kode proses yang telah dimasukkan sebelumnya. Input utama pada proses ini adalah nilai fuzzy synthetic extents kriteria yang terdapat pada database. Hasil proses ini terdapat pada Tabel 6.

Tabel 6 Degree of possibility kriteria

\begin{tabular}{|c|c|c|c|}
\hline Kode Kriteria & Minimal Degree & Normalisasi & Rank \\
\hline AD & 1 & 0.4033 & 1 \\
\hline HG & 0.8339 & 0.3363 & 2 \\
\hline TK & 0.4175 & 0.1684 & 3 \\
\hline KL & 0.2279 & 0.0919 & 4 \\
\hline
\end{tabular}

\subsubsection{Proses Mengecek Rasio Konsistensi Kriteria dan Revising Judgement (Kalau Ada)}

Admin harus memilih kode proses yang telah dimasukkan sebelumnya . Input utama pada proses ini adalah nilai matrik pairwise comparison (TFN) antar kriteria dan normalisasi kriteria dari degree of possibility kriteria yang terdapat pada database. Hasil proses ini terdapat pada Tabel 7. 
Tabel 7 Cek rasio konsistensi kriteria

\begin{tabular}{|c|c|c|c|c|}
\hline Kriteria & AD & HG & TK & KL \\
\hline AD & 1 & 1,6678 & 1,5176 & 0,8282 \\
\hline HG & 0,5996 & 1 & 1,2348 & 0,674 \\
\hline TK & 0,6591 & 0,8098 & 1 & 0,787 \\
\hline KL & 1,2077 & 1,4839 & 1,2706 & 1 \\
\hline Jumlah $\lambda$ & 3,4664 & 4,9615 & 5,023 & 3,2892 \\
\hline \multicolumn{5}{c|}{$\mathrm{n}=4$} \\
$\quad \mathrm{CI}=0,0352$ \\
$\mathrm{RI}=0,9$ \\
CR $=0,0391$ (konsisten) $<=0,1$ dan (nilai +)
\end{tabular}

Karena CR kriteria ini memenuhi, maka tidak perlu revising judgement.

\subsection{Pengujian Proses Melakukan Perhitungan Subkriteria}

\subsubsection{Proses Memberikan Nilai Matrik Pairwise Comparison (TFN) Antar Subkriteria Pada Semua Kriteria}

Admin harus memilih kode proses yang telah dimasukkan sebelumnya. Input utama pada proses ini adalah data subkriteria dan fuzzy linguistik yang terdapat pada database. Hasil proses ini pada administrasi terrdapat pada Tabel 8. Untuk subkriteria pada kriteria yang lain juga memiliki nilai perbandingan antar subkriteria yang sama $(\operatorname{TFN}=(1,1,3)$

Tabel 8 Matrik pairwise comparison (TFN) antar subkriteria pada administrasi

\begin{tabular}{|c|c|c|c|c|c|c|c|c|c|c|c|c|}
\hline \multirow{3}{*}{$\begin{array}{l}\text { Subkriteria } \\
\text { Administrasi }\end{array}$} & \multicolumn{12}{|c|}{ Subkriteria Administrasi } \\
\hline & \multicolumn{3}{|c|}{$\mathbf{A D}_{1}$} & \multicolumn{3}{|c|}{$\mathbf{A D}_{2}$} & \multicolumn{3}{|c|}{$\mathbf{A D}_{\mathbf{3}}$} & \multicolumn{3}{|c|}{$\mathbf{A D}_{4}$} \\
\hline & $l_{1}$ & $\mathbf{m}_{1}$ & $\mathbf{u}_{1}$ & $\mathbf{l}_{2}$ & $\mathbf{m}_{2}$ & $\mathbf{u}_{2}$ & $l_{3}$ & $\mathbf{m}_{3}$ & $\mathbf{u}_{3}$ & $\mathbf{l}_{4}$ & $\mathbf{m}_{4}$ & $\mathbf{u}_{4}$ \\
\hline $\mathbf{A D}_{1}$ & 1 & 1 & 1 & 1 & 1 & 3 & 1 & 1 & 3 & 1 & 1 & 3 \\
\hline $\mathbf{A D}_{2}$ & 0,3333 & 1 & 1 & 1 & 1 & 1 & 1 & 1 & 3 & 1 & 1 & 3 \\
\hline $\mathbf{A D}_{3}$ & 0,3333 & 1 & 1 & 0,3333 & 1 & 1 & 1 & 1 & 1 & 1 & 1 & 3 \\
\hline $\mathbf{A D}_{4}$ & 0,3333 & 1 & 1 & 0,3333 & 1 & 1 & 0,3333 & 1 & 1 & 1 & 1 & 1 \\
\hline
\end{tabular}

\subsubsection{Proses Menghitung Fuzzy Synthetic Extents Subkriteria Pada Semua Kriteria}

Admin harus memilih kode proses yang telah dimasukkan sebelumnya. Input utama pada proses ini adalah nilai matrik pairwise comparison (TFN) antar subkriteria pada semua kriteria yang terdapat pada database. Hasil proses ini terdapat pada Tabel 9.

Tabel 9 Fuzzy synthetic extents subkriteria pada semua kriteria

\begin{tabular}{|c|c|c|c|}
\hline Kode Subkriteria & $\mathbf{S}_{1}$ & $\mathbf{S}_{\mathrm{m}}$ & $\mathbf{S}_{\mathbf{u}}$ \\
\hline $\mathbf{A D}_{1}$ & 0.1428 & 0.25 & 0.833 \\
\hline $\mathbf{A D}_{2}$ & 0.119 & 0.25 & 0.6664 \\
\hline $\mathbf{A D}_{3}$ & 0.0952 & 0.25 & 0.4998 \\
\hline $\mathbf{A D}_{4}$ & 0.0714 & 0.25 & 0.3332 \\
\hline $\mathbf{H G}_{1}$ & 0.2001 & 0.3333 & 1.0003 \\
\hline $\mathrm{HG}_{2}$ & 0.1556 & 0.3333 & 0.7145 \\
\hline $\mathrm{HG}_{3}$ & 0.1112 & 0.3333 & 0.4287 \\
\hline $\mathbf{T K}_{1}$ & 0.111 & 0.2 & 0.7085 \\
\hline $\mathbf{T K}_{2}$ & 0.0962 & 0.2 & 0.5995 \\
\hline $\mathrm{TK}_{3}$ & 0.0814 & 0.2 & 0.4905 \\
\hline $\mathbf{T K}_{4}$ & 0.0666 & 0.2 & 0.3815 \\
\hline $\mathbf{T K}_{5}$ & 0.0518 & 0.2 & 0.2725 \\
\hline $\mathbf{K L}_{1}$ & 0.0664 & 0.1248 & 0.4862 \\
\hline $\mathbf{K L}_{2}$ & 0.0609 & 0.1248 & 0.442 \\
\hline $\mathbf{K L}_{3}$ & 0.0553 & 0.1248 & 0.3978 \\
\hline $\mathbf{K L}_{4}$ & 0.0498 & 0.1248 & 0.3536 \\
\hline $\mathbf{K L}_{5}$ & 0.0443 & 0.1248 & 0.3094 \\
\hline $\mathrm{KL}_{6}$ & 0.0387 & 0.1248 & 0.2652 \\
\hline $\mathbf{K L}_{7}$ & 0.0332 & 0.1248 & 0.221 \\
\hline $\mathrm{KL}_{8}$ & 0.0277 & 0.1248 & 0.1768 \\
\hline
\end{tabular}

\subsubsection{Proses Menghitung Degree of Possibility Subkriteria Pada Semua Kriteria}

Admin harus memilih kode proses yang telah dimasukkan sebelumnya. Input utama pada proses ini adalah nilai fuzzy synthetic extents subkriteria pada semua kriteria yang terdapat pada database. Hasil proses ini terdapat pada Tabel 10. 
Tabel 10 Degree of possibility subkriteria pada semua kriteria

\begin{tabular}{|c|c|c|c|}
\hline Kode Subriteria & Minimum Degree & Normalisasi & Rank \\
\hline $\mathbf{A D}_{\mathbf{1}}$ & 1 & 0,25 & 1 \\
\hline $\mathbf{A D}_{\mathbf{2}}$ & 1 & 0,25 & 1 \\
\hline $\mathbf{A D}_{\mathbf{3}}$ & 1 & 0,25 & 1 \\
\hline $\mathbf{A D}_{\mathbf{4}}$ & 1 & 0,25 & 1 \\
\hline $\mathbf{H G}_{\mathbf{1}}$ & 1 & 0,3333 & 1 \\
\hline $\mathbf{H G}_{\mathbf{2}}$ & 1 & 0,3333 & 1 \\
\hline $\mathbf{H G}_{\mathbf{3}}$ & 1 & 0,3333 & 1 \\
\hline $\mathbf{T K}_{\mathbf{1}}$ & 1 & 0,2 & 1 \\
\hline $\mathbf{T K}_{\mathbf{2}}$ & 1 & 0,2 & 1 \\
\hline $\mathbf{T K}_{\mathbf{3}}$ & 1 & 0,2 & 1 \\
\hline $\mathbf{T K}_{\mathbf{4}}$ & 1 & 0,2 & 1 \\
\hline $\mathbf{T K}_{\mathbf{5}}$ & 1 & 0,2 & 1 \\
\hline $\mathbf{K L}_{\mathbf{1}}$ & 1 & 0,125 & 1 \\
\hline $\mathbf{K L}_{\mathbf{2}}$ & 1 & 0,125 & 1 \\
\hline $\mathbf{K L}_{\mathbf{3}}$ & 1 & 0,125 & 1 \\
\hline $\mathbf{K L}_{\mathbf{4}}$ & 1 & 0,125 & 1 \\
\hline $\mathbf{K L}_{\mathbf{5}}$ & 1 & 0,125 & 1 \\
\hline $\mathbf{K L}_{\mathbf{6}}$ & 1 & 0,125 & 1 \\
\hline $\mathbf{K L}_{\mathbf{7}}$ & 1 & 0,125 & 1 \\
\hline $\mathbf{K L}_{\mathbf{8}}$ & 1 & 0,125 & 1 \\
\hline & & & \\
\hline
\end{tabular}

\subsubsection{Proses Mengecek Rasio Konsistensi Subkriteria Pada Semua Kriteria dan Revising Judgement (Kalau Ada)}

Admin harus memilih kode proses yang telah dimasukkan sebelumnya . Input utama pada proses ini adalah nilai matrik pairwise comparison (TFN) antar subkriteria pada semua kriteria dan normalisasi subkriteria dari degree of possibility subkriteria pada semua kriteria yang terdapat pada database. Hasil proses ini adalah CR subkriteria pada adminstrasi $=0,0438$, CR subkriteria pada teknis $=0,0362, \mathrm{CR}$ subkriteria pada harga $=0,0645, \mathrm{CR}$ subkriteria pada kualifikasi $=0,03$. Ini menunjukkan semua memenuhi rasio konsistensi. Karena semua memenuhi rasio konsistensi, maka tidak perlu revising judgement.

\subsection{Pengujian Proses Menghitung Composite Weight Subkriteria}

Admin harus memilih kode proses yang telah dimasukkan sebelumnya. Input utama pada proses ini adalah normalisasi kriteria dari degree of possibility kriteria dan normalisasi subkriteria dari degree of possibility subkriteria pada semua kriteria yang terdapat pada database. Hasil proses ini terdapat pada Tabel 11.

Tabel 11 Composite weight subkriteria

\begin{tabular}{|c|c|}
\hline Kode Subkriteria & Composite Weight \\
\hline $\mathbf{A} \mathbf{D}_{1}$ & 0.100825 \\
\hline $\mathbf{A D}_{2}$ & 0.100825 \\
\hline $\mathbf{A D}_{3}$ & 0.100825 \\
\hline $\mathbf{A D}_{4}$ & 0.100825 \\
\hline $\mathbf{H G}_{1}$ & 0.11208879 \\
\hline $\mathbf{H G}_{2}$ & 0.11208879 \\
\hline $\mathrm{HG}_{3}$ & 0.11208879 \\
\hline $\mathbf{T K}_{1}$ & 0.03368 \\
\hline $\mathbf{T K}_{2}$ & 0.03368 \\
\hline $\mathbf{T K}_{3}$ & 0.03368 \\
\hline $\mathbf{T K}_{4}$ & 0.03368 \\
\hline $\mathbf{T K}_{5}$ & 0.03368 \\
\hline $\mathbf{K L}_{1}$ & 0.0114875 \\
\hline $\mathbf{K L}_{2}$ & 0.0114875 \\
\hline $\mathrm{KL}_{3}$ & 0.0114875 \\
\hline $\mathrm{KL}_{4}$ & 0.0114875 \\
\hline $\mathbf{K L}_{5}$ & 0.0114875 \\
\hline $\mathrm{KL}_{6}$ & 0.0114875 \\
\hline $\mathbf{K L}_{7}$ & 0.0114875 \\
\hline $\mathrm{KL}_{8}$ & 0.0114875 \\
\hline
\end{tabular}




\subsection{Pengujian Proses Melakukan Perhitungan Untuk Peserta}

3.4.1 Proses Memberikan Nilai Peserta Untuk Semua Subkriteria

Panitia tender harus memilih kode proses yang telah dimasukkan sebelumnya. Input utama pada proses ini adalah dokumen penawaran peserta dan data paket kerja konstruksi, data tender yang terdapat pada database. Hasil proses ini seperti pada Tabel 2.

\subsubsection{Proses Menghitung Fuzzy Synthetic Extents Peserta Untuk Tiap-Tiap Subkriteria}

Panitia tender harus memilih kode proses yang telah dimasukkan sebelumnya. Input utama pada proses ini adalah nilai peserta tender yang terdapat pada database.

\subsubsection{Proses Menghitung Degree of Possibility Peserta Untuk Tiap-Tiap Subkriteria}

Panitia tender harus memilih kode proses yang telah dimasukkan sebelumnya. Input utama pada proses ini adalah nilai fuzzy synthetic extents peserta untuk tiap-tiap subkriteria yang terdapat pada database.

\subsection{Pengujian Proses Menghitung Bobot Akhir Peserta}

\subsubsection{Proses Menghitung Bobot Akhir Peserta Untuk Semua Subkriteria}

Panitia tender harus memilih kode proses yang telah dimasukkan sebelumnya. Input utama pada proses ini adalah composite weight subkriteria dan normalisasi peserta untuk tiaptiap subkriteria dari degree of possibility peserta yang terdapat pada database. Hasil proses ini terdapat pada Tabel 12.

Tabel 12 Bobot akhir peserta untuk semua subkriteria

\begin{tabular}{|c|c|c|c|c|c|c|}
\hline \multirow{2}{*}{ Subkriteria } & $\begin{array}{c}\text { CV. Sri } \\
\text { Karya (SK) }\end{array}$ & $\begin{array}{c}\text { CV. Ari } \\
\text { Wiguna Jaya } \\
\text { (AWJ) }\end{array}$ & $\begin{array}{c}\text { PT. Ubung } \\
\text { Raya (UR) }\end{array}$ & $\begin{array}{c}\text { CV. Asta } \\
\text { Bumi (AB) }\end{array}$ & $\begin{array}{c}\text { CV. Marga } \\
\text { Jaya (MJ) }\end{array}$ & $\begin{array}{c}\text { CV. Artha } \\
\text { Dananjaya } \\
\text { (AD) }\end{array}$ \\
\cline { 2 - 7 } & Bobot Akhir & Bobot Akhir & Bobot Akhir & Bobot Akhir & Bobot Akhir & Bobot Akhir \\
\hline $\mathbf{A D}_{\mathbf{1}}$ & 0.0168 & 0.0168 & 0.0168 & 0.0168 & 0.0168 & 0.0168 \\
\hline $\mathbf{A D}_{\mathbf{2}}$ & 0.0168 & 0.0168 & 0.0168 & 0.0168 & 0.0168 & 0.0168 \\
\hline $\mathbf{A D}_{\mathbf{3}}$ & 0.0168 & 0.0168 & 0.0168 & 0.0168 & 0.0168 & 0.0168 \\
\hline $\mathbf{A D}_{\mathbf{4}}$ & 0.0168 & 0.0168 & 0.0168 & 0.0168 & 0.0168 & 0.0168 \\
\hline $\mathbf{H G}_{\mathbf{1}}$ & 0.0187 & 0.0187 & 0.0187 & 0.0187 & 0.0187 & 0.0187 \\
\hline $\mathbf{H G}_{\mathbf{2}}$ & 0,0261 & 0,0101 & 0,0261 & 0,0261 & 0,006 & 0,0177 \\
\hline $\mathbf{H G}_{\mathbf{3}}$ & 0,0261 & 0,0101 & 0,0261 & 0,0261 & 0,006 & 0,0177 \\
\hline $\mathbf{T K}_{\mathbf{1}}$ & 0.0062 & 0.0052 & 0.0089 & 0.0077 & 0.0034 & 0.0023 \\
\hline $\mathbf{T K}_{\mathbf{2}}$ & 0.0059 & 0.0041 & 0.0075 & 0.0071 & 0.0057 & 0.0034 \\
\hline $\mathbf{T K}_{\mathbf{3}}$ & 0,0078 & 0,003 & 0,0078 & 0,0078 & 0,0018 & 0,0053 \\
\hline $\mathbf{T K}_{\mathbf{4}}$ & 0.0062 & 0.0047 & 0.0075 & 0.0075 & 0.0042 & 0.0035 \\
\hline $\mathbf{T K}_{\mathbf{5}}$ & 0.0056 & 0.0056 & 0.0056 & 0.0056 & 0.0056 & 0.0056 \\
\hline $\mathbf{K L}_{\mathbf{1}}$ & 0.0022 & 0.0022 & 0.0022 & 0.0022 & 0.0022 & 0.0004 \\
\hline $\mathbf{K L}_{\mathbf{2}}$ & 0.003 & 0.0013 & 0.003 & 0.003 & 0.0009 & 0.0004 \\
\hline $\mathbf{K L}_{\mathbf{3}}$ & 0.0022 & 0.0022 & 0.0022 & 0.0022 & 0.0022 & 0.0004 \\
\hline $\mathbf{K L}_{\mathbf{4}}$ & 0.0019 & 0.0019 & 0.0019 & 0.0019 & 0.0019 & 0.0019 \\
\hline $\mathbf{K L}_{\mathbf{5}}$ & 0.0019 & 0.0019 & 0.0019 & 0.0019 & 0.0019 & 0.0019 \\
\hline $\mathbf{K L}_{\mathbf{6}}$ & 0.003 & 0.0013 & 0.003 & 0.003 & 0.0009 & 0.0004 \\
\hline $\mathbf{K L}_{\mathbf{7}}$ & 0.0022 & 0.0004 & 0.0022 & 0.0022 & 0.0022 & 0.0022 \\
\hline $\mathbf{K L}_{\mathbf{8}}$ & 0.0019 & 0.0019 & 0.0019 & 0.0019 & 0.0019 & 0.0019 \\
\hline $\mathbf{T O T}_{\mathbf{2}}$ & 0.1881 & 0.1418 & 0.1937 & 0.1921 & 0.1327 & 0.1509 \\
\hline
\end{tabular}

\subsubsection{Proses Menghitung Total Bobot Akhir dan Merangking Peserta}

Panitia tender harus memilih kode proses yang telah dimasukkan sebelumnya. Input utama pada proses ini adalah bobot akhir peserta untuk semua subkriteria yang terdapat pada database. Hasil proses ini terdapat pada Tabel 13.

Tabel 13 Total bobot akhir dan rangking peserta

\begin{tabular}{|c|c|c|}
\hline Peserta Tender & Total Bobot Akhir & Rangking \\
\hline PT. Ubung Raya (UR) & 0.1937 & 1 \\
\hline CV. Asta Bumi (AB) & 0.1921 & 2 \\
\hline CV. Sri Karya (SK) & 0.1881 & 3 \\
\hline $\begin{array}{c}\text { CV. Artha Dananjaya } \\
\text { (AD) }\end{array}$ & 0.1509 & 4 \\
\hline $\begin{array}{c}\text { CV. Ari Wiguna Jaya } \\
\text { (AWJ) }\end{array}$ & 0.1418 & 5 \\
\hline CV. Marga Jaya (MJ) & 0.1327 & 6 \\
\hline
\end{tabular}

IJCCS Vol. 8, No. 1, January 2014 : $1-12$ 
Hasil dari SPK yang telah diuji memiliki perangkingan peserta yang sama dengan sistem manualnya di Bagian Perlengkapan Rektorat UNUD (rangking 1, 2, 3). Rangking 4, 5, 6 yang juga dihasilkan dari SPK ini tidak terdapat pada sistem manualnya karena ketiga peserta tidak memenuhi evaluasi kriteria kualifikasi (syarat untuk lulus tender adalah memenuhi semua evaluasi kriteria).

Karena ketiga peserta (CV.Sri Karya, PT. Ubung Raya, CV.Asta Bumi) memenuhi semua evaluasi kriteria dan memiliki harga penawaran terkoreksi terendah di bawah HPS yang sama (nilai subkriteria $\mathrm{HG}_{2}$ yang sama), maka dilakukan peninjauan ulang untuk ketiga peserta tersebut terhadap subkriteria $\mathrm{TK}_{1}-\mathrm{TK}_{5}$ agar mencari peserta yang memiliki nilai total terbesar terhadap seluruh nilai subkriteria $\mathrm{TK}_{1}-\mathrm{TK}_{5}$. yang terjadi pada sistem manual.

Jadi disimpulkan bahwa SPK yang dibangun menghasilkan inforamsi valid dan dapat membantu mempercepat pengambilan keputusan dalam kondisi beberapa peserta memenuhi semua evaluasi kriteria dan memiliki harga penawaran terkoreksi terendah di bawah HPS yang sama. Juga hasil perhitungan spreadsheet excel (total bobot akhir) hampir sama dengan perhitungan SPK yang dibangun. Berikut ini terdapat tabel nilai peserta pada sistem manual untuk semua subkriteria, tabel nilai ketiga peserta untuk subkriteria $\left(\mathrm{TK}_{1}-\mathrm{TK}_{5}\right)$ pada sistem manual, dan tabel rangking dari hasil tender pada sistem manual pada Tabel 14, Tabel 15, Tabel $16[5]$.

Tabel 14 Nilai peserta pada sistem manual

\begin{tabular}{|c|c|c|c|c|c|c|}
\hline \multirow{3}{*}{ Subkriteria } & $\begin{array}{c}\text { CV. Sri } \\
\text { Karya } \\
\text { (SK) }\end{array}$ & $\begin{array}{c}\text { CV. Ari } \\
\text { Wiguna Jaya } \\
\text { (AWJ) }\end{array}$ & $\begin{array}{c}\text { PT.Ubung } \\
\text { Raya (UR) }\end{array}$ & $\begin{array}{c}\text { CV. Asta } \\
\text { Bumi (AB) }\end{array}$ & $\begin{array}{c}\text { CV. Marga } \\
\text { Jaya (MJ) }\end{array}$ & $\begin{array}{c}\text { CV. Artha } \\
\text { Dananjaya } \\
\text { (AD) }\end{array}$ \\
\cline { 2 - 7 } & Nilai & Nilai & Nilai & Nilai & Nilai & Nilai \\
\hline $\mathbf{A D}_{\mathbf{1}}$ & AS & AS & AS & AS & AS & AS \\
\hline $\mathbf{A D}_{2}$ & AS & AS & AS & AS & AS & AS \\
\hline $\mathbf{A D}_{3}$ & AS & AS & AS & AS & AS & AS \\
\hline $\mathbf{A D}_{4}$ & AS & AS & AS & AS & AS & AS \\
\hline $\mathbf{T K}_{1}$ & AS & AS & AS & AS & AS & AS \\
\hline $\mathbf{T K}_{2}$ & AS & AS & AS & AS & AS & AS \\
\hline $\mathbf{T K}_{3}$ & AS & AS & AS & AS & AS & AS \\
\hline $\mathbf{T K}_{\mathbf{4}}$ & AS & AS & AS & AS & AS & AS \\
\hline $\mathbf{T K}_{5}$ & AS & AS & AS & AS & AS & AS \\
\hline $\mathbf{H G}_{1}$ & AS & AS & AS & AS & AS & AS \\
\hline $\mathbf{H G}_{2}$ & AS & AS & AS & AS & AS & AS \\
\hline $\mathbf{H G}_{3}$ & AS & AS & AS & AS & AS & AS \\
\hline $\mathbf{K L}_{1}$ & AS & AS & AS & AS & AS & ATS \\
\hline $\mathbf{K L}_{2}$ & AS & ATS & AS & AS & ATS & ATS \\
\hline $\mathbf{K L}_{3}$ & AS & AS & AS & AS & AS & ATS \\
\hline $\mathbf{K L}_{4}$ & AS & AS & AS & AS & AS & AS \\
\hline $\mathbf{K L}_{5}$ & AS & AS & AS & AS & AS & AS \\
\hline $\mathbf{K L}_{6}$ & AS & ATS & AS & AS & ATS & ATS \\
\hline $\mathbf{K L}_{7}$ & AS & ATS & AS & AS & AS & AS \\
\hline $\mathbf{K L}_{\mathbf{n}}$ & AS & AS & AS & AS & AS & AS \\
\hline
\end{tabular}

Keterangan: $\mathrm{AS}=$ ada dan sesuai, $\mathrm{ATS}=$ ada dan tidak sesuai, $\mathrm{TA}=$ tidak ada

Tabel 15 Nilai ketiga peserta untuk subkriteria $\left(\mathrm{TK}_{1}-\mathrm{TK}_{5}\right)$ pada sistem manual

\begin{tabular}{|c|c|c|c|}
\hline \multirow{2}{*}{ Subkriteria } & $\begin{array}{c}\text { CV. Sri } \\
\text { Karya (SK) }\end{array}$ & $\begin{array}{c}\text { PT. Ubung } \\
\text { Raya (UR) }\end{array}$ & $\begin{array}{c}\text { CV. Asta } \\
\text { Bumi (AB) }\end{array}$ \\
\cline { 2 - 4 } & Nilai & Nilai & Nilai \\
\hline TK $_{\mathbf{1}}$ & 7,7 & 9,6 & 8,5 \\
\hline TK $_{\mathbf{2}}$ & 7,9 & 8,6 & 8,3 \\
\hline TK $_{\mathbf{3}}$ & 9 & 9 & 9 \\
\hline TK $_{\mathbf{4}}$ & 8,8 & 9,5 & 9,5 \\
\hline TK $_{\mathbf{5}}$ & 10 & 10 & 10 \\
\hline TOTAL & $, 43,4$ & 46,7 & 45,3 \\
\hline
\end{tabular}


Tabel 16 Rangking peserta pada sistem manual

\begin{tabular}{|c|c|}
\hline Peserta Tender & Rangking \\
\hline PT. Ubung Raya (UR) & 1 \\
\hline CV. Asta Bumi (AB) & 2 \\
\hline CV. Sri Karya (SK) & 3 \\
\hline
\end{tabular}

\section{KESIMPULAN}

Berdasarkan pembahasan yang telah diuraikan, maka diambil kesimpulan, yaitu:

1. Sistem Pendukung Keputusan (SPK) yang dibangun dengan metode Fuzzy Analytical Hierarchy Process (Fuzzy AHP) untuk menentukan pemenang tender pekerjaan konstruksi (tidak kompleks) dapat membantu pengambil keputusan (panitia tender) dalam menghasilkan perangkingan peserta tender yang valid dan cepat.

2. Sistem Pendukung Keputusan (SPK) yang dibangun dengan metode Fuzzy AHP dapat menampilkan tahap-tahap perhitungan Fuzzy AHP dengan jelas, sehingga admin dan panitia tender mengerti jalan proses metode tersebut.

3. Sistem Pendukung Keputusan (SPK) yang dibangun bersifat dinamis karena data master yang dapat ditambah, diubah, atau dihapus; perhitungan untuk nilai matrik pairwise comparison (TFN) antar kriteria/subkriteria dan untuk nilai peserta tender dapat diubah

\section{DAFTAR PUSTAKA}

[1] Chan, F.T.S., et.al., 2008, Global Supllier Selection: A Fuzzy-AHP Aprroach, International Journal of Production Research, No. 14, Vol. 46, 3825-3857

[2] Huang, C., Chu, P., and Chiang, Y., 2008, A Fuzzy AHP Application In GovernmentSponsored R\&D Project Selection, The International Journal of Management Science (Omega 6), 1038-1052

[3] Hsieh, T.Y., Lu, S.T., and Tzeng, G.H., 2004, Fuzzy MCDM Approach for Planning and Design Tenders Selection In Public Office Buildings, International Journal of Project Management 2, 573-584

[4] Parwati, N.M.D., 2010, Rancang Bangun Sistem Pendukung Keputusan Pemilihan Karyawan Teladan Menggunakan Metode Fuzzy AHP, Skripsi, Jurusan Sistem Informasi, STIKOM, Surabaya

[5] Pejabat Pembuat Komitmen Universitas Udayana, 2010, Surat Perjanjian Kerja (Kontrak) Pembangunan Gedung Kuliah Fakultas Ekonomi Universitas Udayana, Univerrsitas Udayana, Bali 